\title{
GENDER DIFFERENCE AMONG EMPLOYEES WORKING IN DIPLOMATIC MISSIONS
}

\author{
Farkhanda Warsi \\ PhD Scholar, \\ Department of International Relations, \\ University of Sindh, \\ Jamshoro \\ fariwarsi88@gmail.com
}

\begin{abstract}
This study was conducted to examine the gender differences among men and women employees working in Diplomatic Missions. The area of the study was different Diplomatic Missions of different countries and their employees both men and women. The random sampling technique was used to select 24 employees working in diplomatic missions as a sample for the study. Out of 24 employees, 12 were women and 12 were men. Data was collected through questionnaire developed by researcher. The reliability of the questionnaire came out to be .759 for number of employment opportunities and 0.892 for position in office hierarchy. Data collected through questionnaire was analyzed through quantitative means and the data collected was presented in percentage and frequencies and to test the hypothesis paired sample Independent t-test was applied. Findings of this study indicated that gender difference exists between men and women employees working in Diplomatic Missions, the ratio of women employees was less on top position in most of the Diplomatic Missions as compared to men. Moreover, men and women not treated equally in number of employment opportunities. Therefore, it is recommended that authorities of Diplomatic Missions should treated equally of both employees in terms of number of employment opportunities, and top positions in diplomatic missions.
\end{abstract}

KEY Words: Gender, Difference, Employees, Women, Men, Diplomatic Missions. 


\section{Introduction}

According to the English Encyclopedia (2014) Gender differentials refer to the unequal social and economic resources distribution between men and women. According to (WEF) World Economic Forum (2018) report, the gender gap is observed in four categories, Political Empowerment, Health and Survival, Educational Attainment, and Economic Participation. Similarly, gender difference has been seen in all fields of life, from domestic level to professional level, such as difference in education, designation / positions, opportunities, income, decision making power, accesses, effective worker and etc.

In less developed countries females have limited advantages in autonomy because of kingship and patriarchal society. This kingship and patriarchal system hinders women's participation in the development of the country and also this led to the gender differences, pervasive in all spheres of life. Rao, Sandler, Kelleher and Miller (2016) cited the report of the World bank 2011 in their book published in 2016, according to which investment on gender equality can foster improvement in various sectors such as: education, agriculture and health . Moreover, if we encourage women participation in different fields then we can reduce poverty as well. As International Relations are reflective in the whole world therefore the status of women in world affairs should be the same or similar as of men. According to research completed by Rehman (2011), the status of men and women are different in world affairs, Similarly the diplomatic mission is the place where men's and women are considered different and mostly men are top representative of a country.

As example of gender differences between women and men, women earn less as compared to men and mostly women are fewer in executive levels, but women economic participation mostly unpaid within home or out of home. Generally, women earn less as compared to men. Women voices weigh less here in decision making processes and women have less control own material or even own personal decisions. Female participation in labor force female is high in East and Pacific Asia 64\%, South Asia 35\% 


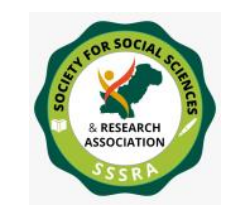

and lowest in North Africa and Middle east 26\%, (World Bank, 2012). According to the reporter, Pakistan director of Population Council, Dr. Zeba Sathar said in the Labor Force Survey 2014-2015, in Pakistan labor force participation rate among the youth (between, the ages of 10 and 24) is $41.3 \mathrm{pc}$ for male and 16.4 for female. ("Govt should focus on skill development", 2016). MaDonnell (2013) cities a report Global Gender Gap (2013) that, Japan is the top of the country where gender gap more exists as compared to other countries western and European.

According to Mehboob (2016), in Pakistan the women legislator's performance improved as compared to male counterparts in both (national parliament and provincial legislature) in the last 13 years. Wilson (2014) cites, the World Economic Forum's index ranking which confirms that, East Asian women in politics and education are fewer as compared to men. According to the research study (ISDS, 2015), in Vietnam only $2 \%$ of men do not work as compared to above $20 \%$ women due to household responsibilities. Moreover, women rarely get a chance to obtain higher positions and in professional trainings. Slowly and gradually women are rising in the field of diplomacy and in international movements, but the gap still exists. According to Towns and Nikasson (2017) males predominantly occupied the post of Ambassador while females still lag behind such upper positions as compared to their male counterparts. Men tend to share more within the field of mediators in peace negotiations. This gender difference pattern impacts on International Affairs.

At the beginning of the 20th century, the women role in the Ministry of Foreign Affairs was severely limited: married women could not take foreign services exam, only single women. Women became accepted in the career of foreign services in 1918 in Brazil, 1920 in the US, 1932 in Turkey, 1934 in Denmark, 1939 in Norway, and 1949 in Japan, (Aggestam and Towns, 2018). Human resources are the main powerful tool for the success of any organization. Employees are the main assets of any organization, and if the employees feel comfort and equality, so they work better. Therefore, in order to shed light on the gender differences among employees working in diplomatic missions, this research has pinpointed a set of variables for gender differences which includes the number of 
employment opportunities and gender difference on top position between men and women in diplomatic missions.

Remaining this paper has been divided into six sections, the first section outlines the Rationale of the study. It will enhance the importance of this research paper, why this research paper has been done, the need for the research and what is the problem. The second section, the Objectives of the study and the hypothesis, here objectives and hypothesis have been made. The third section will present the Literature Review regarding gender difference in different fields such as, men and women differences in education, men and women differences in labor force participation/employment opportunities, men and women differences in income, men and women differences in authority or decision-making power or etc. in the diplomatic missions and other organizations as well. The fourth section presents the research methodology and describes which design, method etc. have been used in this research. The fifth section explains the data analysis and discusses it. The sixth section provides recommendations and concludes the research.

\section{Rational of the study}

Gender differences are a very common phenomenon among men and women employees working in different organizations including in the diplomatic services. The public dealing is very hectic in all types of diplomatic missions whether they are in embassies and consulates. Among the visitors and customers, both men and women but it is still male dominancy in the employment opportunities in most of the diplomatic missions. The ratio of the female's employees in the diplomatic missions is feeble. According to Rehman (2011:17), there are limited promotional opportunities within embassies, so female at the bottom of the hierarchy are more inclined to feel instinctively inexpert in their positions. Hence, the research problem under investigation is "GENDER DIFFRENCE AMONG EMPLOYEES WORKING IN DIPLOMATIC MISSIONS OF ASIAN, WESTERN AND EUROPEAN COUNTRIES".

\section{Objective of the Study}


1. To explore the difference in employment opportunities for men and women working in diplomatic missions.

2. To explore the difference on top positions of men and women employees in diplomatic missions.

\section{Research hypotheses}

1. $\mathrm{H}_{1}$ : The number of employment opportunities for women and men are different in diplomatic missions.

$\mathrm{H}_{0}$ : The number of employment opportunities for women and men are not different in diplomatic missions.

2. $\mathrm{H}_{1}$ : There is significant differences on top positions of men and women employees in diplomatic missions.

$\mathrm{H}_{1}$ : There is no significant differences on top positions of men and women employees in diplomatic missions

$\mathrm{H}_{1}$ : The women employees are less on top position as compared to men in diplomatic missions.

$\mathrm{H}_{0}$ : The women employees are not less on top position as compared to men in diplomatic missions.

\section{Literature Review}

According to (Miller, et al. 1992) females are more appropriate for the household tasks/management, childcaring, and nurturing. Similarly (Pleck, 1977) says that usually, females were anticipated for the home makers task whereas males were considered to be wage earners. However, in the past century, gender composition in the workforce was different and now this gender composition in the workforce has increased compared to previously and the number of women entered into the labor force. (Bhalla and Kaur, 2011; Van Vianen and Fischer, 2002; Schwartz, 1989; Miller, 1978). On the other hand, it is observed that men have tended to monopolize the posts in diplomatic services, the international civil services, and the military. Until 1987 United States was founded to have less than 3 percent females occupying the senior Foreign Office positions. 
For some, the voice of women in International Politics is considered "inauthentic". (Tickner, 1992).

In old times, women have been facing difficulties in terms of education and accesses to power positions. Marriage was necessary for women for protection and support. Moreover, women were supposed to produced children. Even in the most developed countries such as in America and Europe no women had the legal right over own land, money, etc. (Kumari, 2012: 1,2). According to OECD (2015), reports on gender related problems, there are still barriers between men and women in employment and education. Both the he partners countries and OECD aims to promote and improving policies related to gender equality. Rana (2013) describes in his book, in Saudi Arabia where restrictions on women are high in the areas such as in employment and dress code. In the US, the requirement of Foreign Diplomatic Services, to resign upon marriage was dropped in 1971 in the Foreign Diplomatic Services.

Female autonomy on the world level observed low as compared to men high. According to the (Jejebhoy, 2002) research findings show that women were limited access in terms of economic resources, purchasing and selling items. Furthermore, no woman can purchase and sell items without consulting a family member and husband. Moreover, the study shows that the women's participation in decision making is limited. Tsalikis (2018) writes in her article in 1995 that the first female ambassador appointed by Canada to the (UN) United Nations was a political appointee. Similarly, in 2016-2017, two female officers were political appointee. Therefore, women those are coming in the diplomatic missions are politically appointed.

Shilling, J. (2014), throughout in the two worlds wars in diplomatic services, the role of women was different. The British diplomatic and consular services committee concluded in 1936 that women were still disadvantages or made no profit in the field of diplomatic services in all over the world. Tsalikis (2018) writes in her article that in 1909 in Canada, only men could apply to the foreign services examinations in upper level jobs and women could only apply as clerk or secretaries. Moreover, 
women were allowed to become officers in the foreign services only from 1947. Before the 1970s married women were not allowed to post abroad, but in the 1971 the changes occurred in the rules and regulations and government removed these limits from married women in all government sectors. Therefore, gender differences in diplomatic missions was exist in Western and European countries.

Shilling, J. (2014), throughout in the two worlds wars in diplomatic services, the role of women was different. The British diplomatic and consular services committee concluded in 1936 that women were still disadvantages or made no profit in the field of diplomatic services in all over the world. Tsalikis (2018) writes in her article that in 1909 in Canada, only men could apply to the foreign services examinations in upper level jobs and women could only apply as clerk or secretaries. Moreover, women were allowed to become officers in the foreign services only from 1947. Before the 1970s married women were not allowed to post abroad, but in the 1971 the changes occurred in the rules and regulations and government removed these limits from married women in all government sectors. Therefore, gender differences in diplomatic missions was exist in Western and European countries.

Bryce (1989) underlines the fact that the advanced standard set for women to obtain equal status at the workplace requires to be more qualified, to work harder, to be more determined and capable than men. Nevertheless, women still do not reach commanding positions with the similar autonomy as compared to men, (Bryce, 1989). According to Baker and Mckenzie (2001) women continue to be deprived in upper positions. Women seems almost invisible, since few have been leaders of states. Women lag behind in such positions, because of continuing to look after the elderly at home, the children and of being more engaged in household work, (Tsalikis, 2018).

China, which is a developing country faces different challenges such as social development, economic development or in gender equality (Dan, 2013). "The gaps exists between women and men in these areas: employment, resources and income," says Song Xiuyan . (Dan, 2013). 


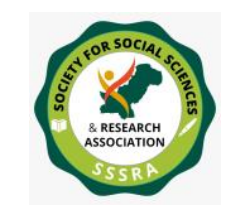

According to Wilson (2014) cites, Harris Rimmer from Australian National University (ANU) notes that Asia produces female leaders in politics but there are few women working at the national level and those who do come political elite. After 1945, the number of women gradually increased in diplomacy both serving as a representative/ambassador by career progression and political appointment. (Marks, 2014:13).

The research study conducted by the Institute for Social Development Studies (2015) finds that Vietnamese women are less educated than men. Yong women are supposed to perform household responsibilities and they sacrifice and give up their education. According to Rehman (2012:2), before the 1970s no women was selected Head of British representative post or in diplomatic services and until 1987 no married women was appointed as a Head of embassy or consulate. Moreover, a female ambassador in New Dehli from the side of United States, but for Russia, China and Japan ,no female Foreign Service Officer visit there as a representative; and the two female who working as representatives to Paris and London were both political appointees (Rana, 2013). Furthermore, she argues in her article that the Reform of diplomacy is closely related to the gender and observe the enclosure and elimination of women, men and transgenders. Therefore, the experts appear to be concerned with the changes within diplomacy. Moreover, they suggest that research on gender and diplomacy should rely on larger numbers (Aggestam et al, 2018).

Rehman (2011:3) also asserts that before 1946 Britain was far more likely to appoint a female within the diplomatic services than was the rest of the world. We can conclude from the literature that the more women are members of a male dominated patrical society the more they are prevented from reaching the top positions in diplomatic services. The same argument applies to the limited promotional opportunities within embassies, and in consequences females at the bottom of hierarchy are more inclined to feel instinctively inexpert in their positions (Rehman, 2011:17).

\section{Methodology}


The descriptive research design used for this study is the following: the quantitative research approach was followed. The questionnaire was used for the data collection process which was developed by researcher. Five-point (05) Likert scale (1=Don't know, 2=Never, $3=$ Sometimes, 4=Frequently, 5= Always) was used in the closed ended questionnaire. Moreover, the questionnaire was divided into two parts: demographics including gender, marital status, and gender difference in number of employments opportunities and gender wise designations/positions. The population of the of the study comprised of employees both men and women working in embassies and consulates of North East and South East Asian, Western and European countries. Through the random sampling selection technique, the sample from the population was selected. Twenty-four $(\mathrm{N}=24)$ respondents, 12 women and 12 men were selected as sample of the study. The questionnaire reliability was calculated from the Cronbach alpha which came out to be 0.759 for number of employment opportunities and 0.892 for position in office. The given values were much higher than 0.6, therefore the range of Alpha shows a good reliability of scale. The findings were explained through tables and description. Furthermore, to test the hypothesis paired Independent Sample t-test was applied.

Data Analysis and discussion Gender wise frequency and percentage of respondent, the number of men were 12 out of 24 and percentage from selected sample were $50 \%$, and the number of women were 12 and the percentage from selected sample were $50 \%$. 


\section{Gender Wise Percenatge of Respondent in the Sample of $\mathbf{N}=24$}

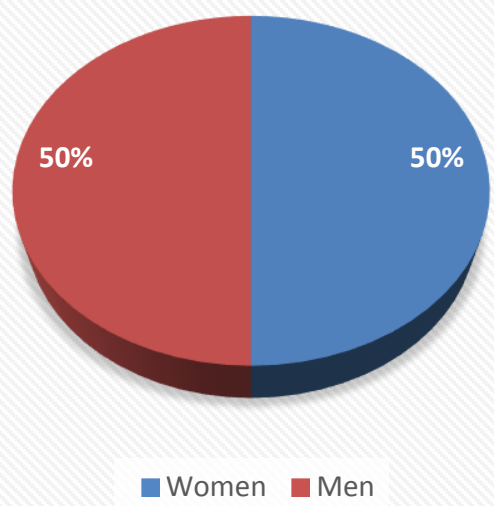

This graph shows the diagrammatical illustration of percentage $(\%)$ of women and men employees of diplomatic missions.

Table:1. Demographic Data Percentage (\%) of respondents (Women and Men employees working in Diplomatic Missions)

\begin{tabular}{|c|c|c|}
\hline Parameters & Category & Percentage \\
\hline \multirow{2}{*}{ Gender } & Men & $50 \%$ \\
\cline { 2 - 3 } & Women & $50 \%$ \\
\hline \multirow{3}{*}{$\begin{array}{c}\text { Marital Status } \\
\text { Women }\end{array}$} & Single & $66.7 \%$ \\
\cline { 2 - 3 } & Married & $25 \%$ \\
\cline { 2 - 3 } & Others & $1 \%$ \\
\hline \multirow{3}{*}{$\begin{array}{c}\text { Marital Status } \\
\text { Men }\end{array}$} & Single & $16.7 \%$ \\
\cline { 2 - 3 } & Married & $83.3 \%$ \\
\cline { 2 - 3 } & Others & $00 \%$ \\
\hline
\end{tabular}


The above table describe that $50 \%$ respondents were men employees. On the other hand, $50 \%$ were women employees. Moreover, the data was collected from both women and men employees (100.0\%). As above this $66.7 \%$ women employees were single as compared to men $16.7 \%$ were single. While $25 \%$ women employees were married and $1 \%$ others (such as widows/divorced), and $83.3 \%$ men employees were men married and 00 percent others. This marital status between men and women shows that single women are more in these missions as compared to single men. Moreover, married women are less in these missions as compared to men.

Table:2. Gender Difference in Employemnt Opportunities

\begin{tabular}{|c|c|c|c|c|c|}
\hline \multirow[t]{2}{*}{$\begin{array}{l}\text { S.N } \\
\text { o: }\end{array}$} & \multirow[t]{2}{*}{$\begin{array}{l}\text { Employment } \\
\text { Opportunities }\end{array}$} & \multicolumn{2}{|c|}{$\begin{array}{l}\text { Men and Women } \\
\text { Treated Equally }\end{array}$} & \multicolumn{2}{|c|}{$\begin{array}{c}\text { Men and Women } \\
\text { Not Treated } \\
\text { Equally } \\
\end{array}$} \\
\hline & & $\begin{array}{c}\text { Frequen } \\
\text { cy }\end{array}$ & $\begin{array}{c}\text { Percenta } \\
\text { ge }\end{array}$ & $\begin{array}{c}\text { Frequen } \\
\text { cy }\end{array}$ & $\begin{array}{c}\text { Percenta } \\
\text { ge }\end{array}$ \\
\hline 1. & $\begin{array}{l}\text { Recruitment and } \\
\text { Selection }\end{array}$ & 4 & $16.7 \%$ & 20 & $83.3 \%$ \\
\hline 2 & Remuneration & 1 & $4.2 \%$ & 23 & $95.8 \%$ \\
\hline 3 & Leave & 5 & $20.8 \%$ & 19 & $79.2 \%$ \\
\hline 4 & $\begin{array}{l}\text { Appraisal/Perform } \\
\text { ance Management }\end{array}$ & 3 & $12.5 \%$ & 21 & $87.5 \%$ \\
\hline 5 & $\begin{array}{c}\text { Training } \\
\text { Development }\end{array}$ & 2 & $8.3 \%$ & 22 & $91.7 \%$ \\
\hline 6 & Accommodation & 3 & $12.5 \%$ & 21 & $87 \%$ \\
\hline 7 & Progression & 2 & $8.3 \%$ & 22 & $91.7 \%$ \\
\hline 8 & Supervision & 3 & $12.5 \%$ & 21 & $87.5 \%$ \\
\hline 9 & Job Security & 2 & $8.3 \%$ & 22 & $91.7 \%$ \\
\hline & & Total $=25$ & & $\begin{array}{c}\text { Total }= \\
191\end{array}$ & \\
\hline
\end{tabular}

Table 2 shows $16.7 \%$ of the respondents reported that in the recruitment and selection processes women and men treated equally. while $83.3 \%$ respondents reported that in the recruitments and selection processes women and men not treated equally. Similarly, $4.2 \%$ respondents 
considered for remuneration men and women treated equally while $95.8 \%$ respondents considered they were not.

Moreover, table 2 shows a total 25 frequency of the respondents who reported that both men and women were treated equally in terms of recruitment and selection, leave, appraisal/ performance management, remuneration, accommodation, training development progression, supervision and job security which is low frequency as compared to a total of 191 frequency where men and women not treated equally.

Therefore, our first alternative hypothesis according to which the number of employment opportunities for men and women are different in these diplomatic missions- is validated.

\section{Gender Difference on top Positions}

Table:3. Paired Samples Statistics

\begin{tabular}{|ll|r|r|r|r|}
\hline & Mean & $\mathrm{N}$ & \multicolumn{1}{c|}{$\begin{array}{c}\text { Std. } \\
\text { Deviation }\end{array}$} & $\begin{array}{c}\text { Std. Error } \\
\text { Mean }\end{array}$ \\
\hline \multirow{2}{*}{ Pair 1 } & Ambassador & 2.5833 & 24 & 1.21285 & .24757 \\
& WOMEN & & 24 & 1.10335 & .22522 \\
\hline
\end{tabular}

Paired Samples Test

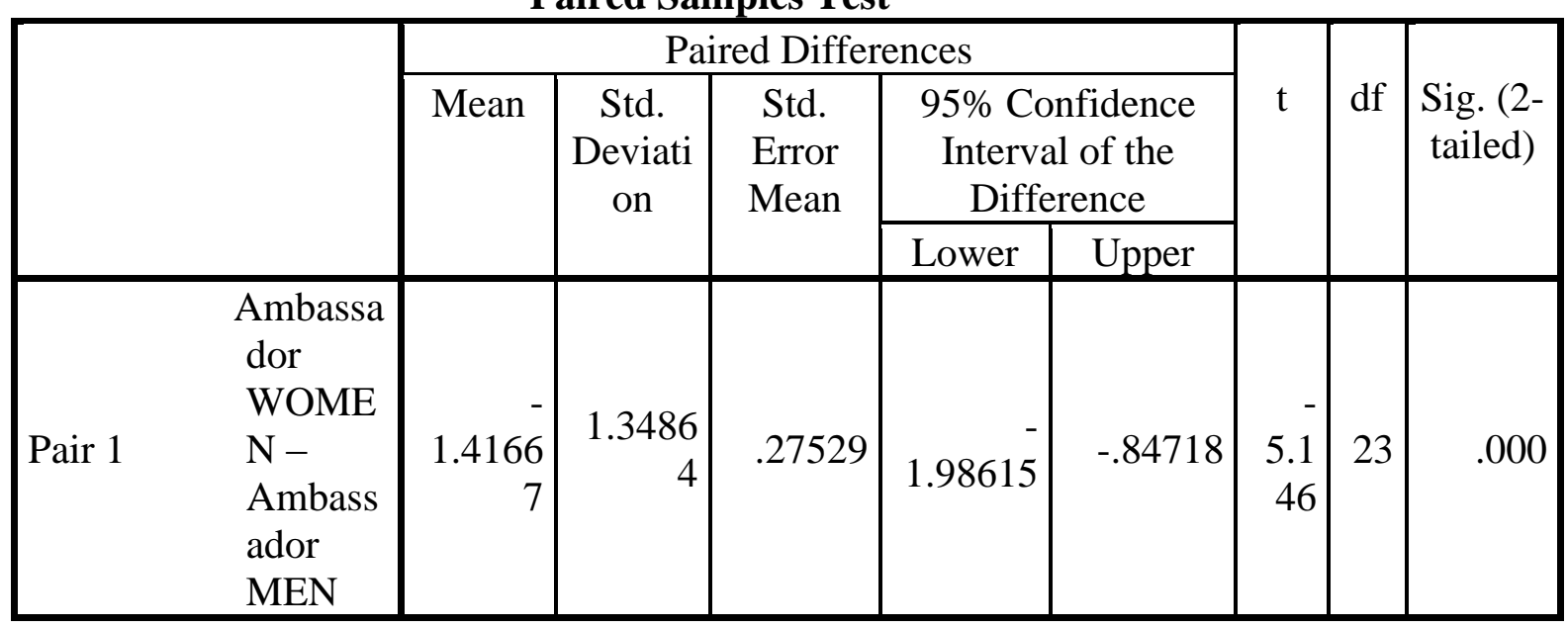


The statistical technique T-test and the type of paired samples t-Test was used to compare gender difference on top positions between men and women in diplomatic missions such as Ambassador. There was a significant difference in the score of women $(\mathrm{M}=2.5, \mathrm{SD}=1.21)$ and men $(\mathrm{M}=4, \mathrm{SD}=1.10) ; \mathrm{t}(23)=-5.14, \mathrm{p}=.000$. These results indicate that the number of men in an Ambassador position is superior to that of women.

Table:4. Paired Samples Statistics

\begin{tabular}{|rl|r|r|r|r|}
\hline & Mean & $\mathrm{N}$ & \multicolumn{1}{c|}{$\begin{array}{c}\text { Std. } \\
\text { Deviation }\end{array}$} & $\begin{array}{c}\text { Std. Error } \\
\text { Mean }\end{array}$ \\
\hline \multirow{2}{*}{ Pair 1 } & Consul & 2.8333 & 24 & 1.30773 & .26694 \\
& Consul MEN & 3.8333 & 24 & 1.20386 & .24574 \\
\hline
\end{tabular}

Paired Samples Test

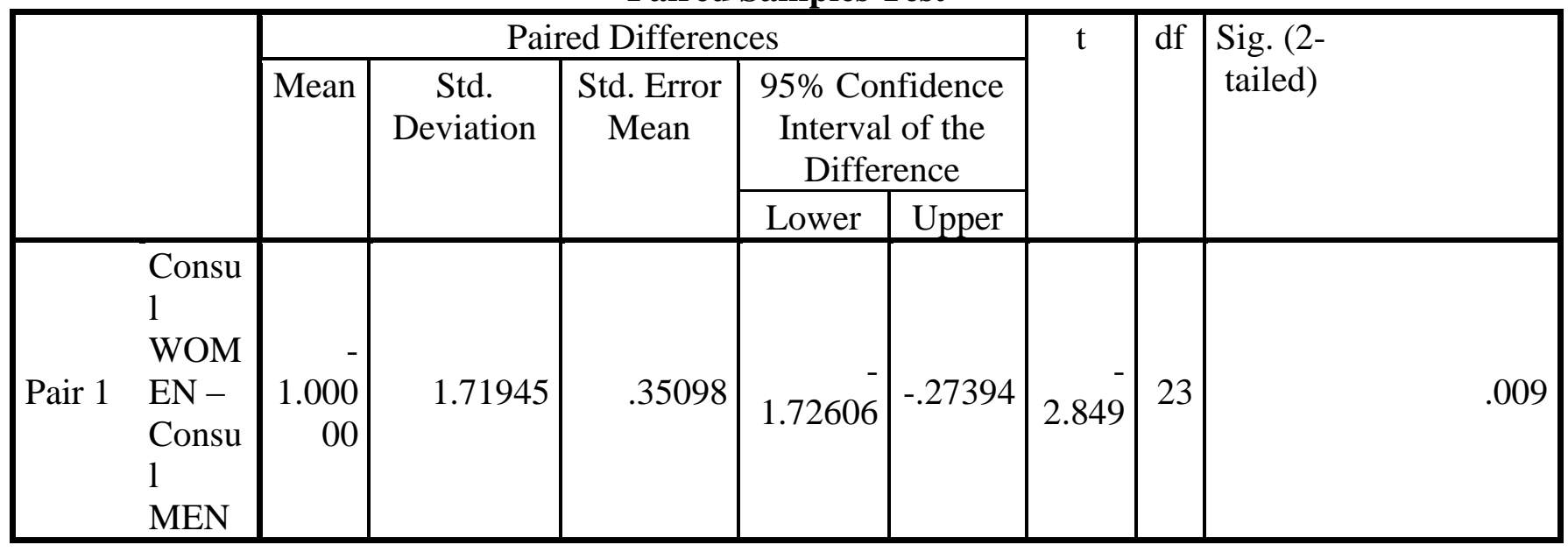

Similarly, the type of paired samples t-Test was used to compare gender difference on top positions between men and women in diplomatic missions such as Consul. There was a significant difference in the score of women $(\mathrm{M}=2.8, \mathrm{SD}=1.30)$ and men $(\mathrm{M}=3.8, \mathrm{SD}=1.20)$; $\mathrm{t}(23)=-2.84, \mathrm{p}$ $=.009$. These results indicate that women are less and men on Consul positions are more than women. 


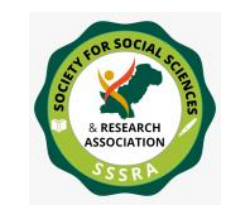

According to the (Towns and Nikasson, 2017), at the beginning all over the world, women entry in the Foreign Office was not easy because of male dominated or patriarchal society. Women have increased in the field of diplomacy $25 \%$ to $40 \%$ of women are now positioned at an ambassador post but most women tend to become junior level diplomats, and male are more likely occupy an ambassadorship and female are still behind from such upper position as compared male counter parts. Tsalikis (2018), tells us that in 2013 only $29 \%$ women and $71 \%$ men were top diplomats, in 2017 this composition increased that was $44 \%$ women and $56 \%$ men was appointed as a top diplomate in Canada a western or North American country. Moreover, in 2016-2017, the two female foreign services officers appointed were political appointee. In 2016 women $36 \%$ of women ambassadors were American and in 2017, $19 \%$ of women ambassadors were British but still only three (3) Canadian women serving as a foreign minister and zero (0) Canadian women serving as a deputy minister even not through political appointee on top positions , (Tsalikis, 2018).

Therefore, our second alternative hypothesis- according to which women employees are less on top position as compared to men in diplomatic missions- is validated.

\section{Recommendation}

According to findings, this study is recommended that authorities of the Diplomatic Services of North East and South East Asian, Western and European countries should reduce the difference between men and women employees in Diplomatic Missions. The organization should seek to balance between both genders the various employment opportunities such as recruitment and selection, leave, appraisal/ performance management, accommodation, remuneration, progression, supervision, training development and job security process. By knowing this one can adjust the gender balanced successfully in Diplomatic Missions.

Moreover, based on yearly or at least six-month duration, authorities should regulate the employees from their positions/ designations through which everyone would get the chance to apply for top positions such as 
Ambassador, or Consul etc. We have to understand that the diplomatic service is not only for men, but women can also do better performance if equal opportunities are to be given to both, men and women without any differences.

\section{Limitations}

This study has conducted gender differentials among employee's male and female working in diplomatic missions of Asian, Western and European countries in future same study can be conducted a comparative study. Second, same study can be conducted only European, only North East and South East Asian countries and others as well. Third, as this study is based on quantitative approach therefore it is also recommended that for future study can be based on qualitative approach or mix method approach.

\section{Conclusion}

This study concludes that gender difference still exists in diplomatic missions between employees' women and men. The findings show, there is difference in number of employment opportunities between women and men. Men and women treated differently in terms of recruitment and selection, leave, remuneration, accommodation, appraisal/ performance management, progression, supervision, training development and job security.

Similarly, in response of second objective to identify the difference on the top positions of women and men employees found in diplomatic missions mostly men were found on top positions such as ambassador and consul positions as compared to women. Therefore, to reduce this gape, experts should take a serious action and should balance both women and men in these diplomatic and consular services. 


\section{REFERENCES}

Aggestam, K., \& Towns, A. (2019). The gender turn in diplomacy: a new research agenda. International Feminist Journal of Politics, 21(1), 928. https://www.tandfonline.com/doi/abs/10.1080/14616742.2018.14832 06?needAccess=true\#aHR0cHM6Ly93d3cudGFuZGZvbmxpbmUu Y29tL2RvaS9wZGYvMTAuMTA4MC8xNDYxNjc0Mi4yMDE4Lj E0ODMyMDY/bmVlZEFjY2Vzcz10cnV1QEBAMA==

Baker, A., \& McKenzie, H. N. (2011). More Women in Senior Positions not pay disparity, major issue facing women in business. An international Journal, 24(6), 388-411.

Bhalla, S. and Kaur, R. (2011), "Labour force participation of women in India: some facts, some queries", Working Paper, 40, London: Asia Research Centre, London School of Economics and Political Science.

Bryce, L. (1989). The influential women: How to achieve success without losing femininity. London: Judy Piatkus.

Dan, H. (2013, May 16). Gender Income Gap Continues to widen China. China Daily. http://www.chinadaily.com.cn/china/2013$\underline{\text { 05/16/content_16502360.htm }}$

Encyclo.co.UK English Encyclopedia (2014). Gender Differentials. website, $\quad$ http://www.encyclo.co.uk/meaning-ofgender\%20differentials

Marks, S. (2014). Diplomacy: The role of women. Encyclopedia Britannica.

http://www.britannica.com/ebchecked/topic/164602/diplomacy/23 3757/The-role-of-women 
Mehboob. A.B. (2016, November 7). Women's Legislative Performance. Dawn. https://www.dawn.com/news/1294681

Miller, A. R. (1978). Changing work life patterns: A twenty-five year review. The Annals of the American Academy of Political and Social Science, 435(1), 83-95.

Miller, V. D., Jablin, F. M., Casey, M. K., Lamphear-Van Horn, M., \& Ethington, C. (1996). The Maternity Leave as a Role Negotiation Process. Journal of Managerial Issues, 286-309.

Pleck, J. H. (1977). The Work-Family Role System. Social Problems, 24(4), 417-427.

Rana, K. S. (2013). The Contemporary Embassy: Paths to Diplomatic Excellence. Basingstoke Palgrave Macmillan. 123-125.

Rao, A., Sandler, J., Kelleher, D., Miller, C. (2016). Gender at Work: Theory and Practice for 21st Century Organizations. New York: Routledge

Rehman, T. (2011). Women in Diplomacy. http://www.unc.edu/depts/diplomat/item/2011/0104/comm/rahman _women.html

Rehman, T. (2012). Celebrating the role of women in diplomacy. http://www.diplomaticourier.com/news/topics/diplomacy/1374celebrating-the-rise-of-women-in-diplomacy

Schwartz, F.N. (1989). Management women and the new facts of life. Managing people. Harvard Business Review. https://hbr.org/1989/01/management-women-and-the-new-facts-of$\underline{\text { life }}$

Shilling, J. (2014). A woman diplomat? It's just not on, chaps! The pioneering females who proved the Foreign Office wrong. 
http://www.dailymail.co.uk/home/books/articale-2662986/Awomen-diplomat-Its-just-not-chaps.html.

Tickner, A, J. (1992). Gender in International Relations: Feminist Perspectives on Achieving Global Security. New York: Columbia University Press.

Tsalikis, C. (2018, April 3). The making of a gender-balanced foreign service. Open Canada. https://www.opencanada.org/features/making-gender-balancedforeign-service/

Van Vianen, A. E., \& Fischer, A. H. (2002). Illuminating the glass ceiling: The role of organizational culture preferences. Journal of Occupational and Organizational Psychology, 75(3), 315-337.

Wilson, K. (2014, May 16). Addressing Asia's Gender Gap Challenges. China Daily. http://www.chinadailyasia.com/asiaweekly/2014$\underline{05 / 16 / \text { content } 15135545 . h t m l}$

World Economic Forum. (2018). The Global Gender Gap Report. Insight Report Geneva: World Economic Forum. http://www3.weforum.org/docs/WEF_GGGR_2018.pdf 